\title{
ANALISIS PROSPEK PENGEMBANGAN PEMBENIHAN IKAN KERAPU (EPINEPHELUS) DI BALAI BUDIDAYA AIR PAYAU ACEH BESAR
}

\author{
Desy Puspita ${ }^{1 *}$, Lisnawati ${ }^{2}$, Indra Akbar ${ }^{3}$, Azlina $^{4}$, Arie Andina ${ }^{5}$ \\ ${ }^{1}$ Program Studi Manajemen Keuangan Sektor Publik Politeknik Kutaraja \\ ${ }^{2,4}$ Program Studi Analis Keuangan Politeknik Kutaraja \\ ${ }^{3}$ Program Studi Administrasi Perkantoran Politeknik Kutaraja \\ ${ }^{5}$ Program Studi Akuntansi Politeknik Kutaraja \\ Telp. 0651- 8016378 \\ *Email: andaresta.desy@gmail.com
}

\begin{abstract}
ABSTRAK
Tujuan penelitian ini adalah untuk mengetahui kelayakan pengembangan pembenihan ikan kerapu di Balai Budi Daya Air Payau Aceh Besar. Metode yang digunakan studi kasus karena mengungkapkan suatu kebenaran yang menitik beratkan hanya pada satu objek penelitian yaitu pembenihan ikan kerapu pada BBAP Ujung Batee Kecamatan Mesjid Raya Kabupaten Aceh Besar. Batasan variable yang digunakan meliputi biaya produksi, produksi, nilai produksi, harga, keuntungan, tenaga kerja, nilai ekonomis dan SWOT. Model analisis yang digunakan pada penelitian ini hanya sebatas pada Analisis SWOT dan Analisis Finansial serta beberapa analisis pendukung kainnya seperti Pay Back Periods dan Analisis Sensitivitas
\end{abstract}

Keyword: Analisis Kelayakan Usaha, ikan kerapu, SWOT

\section{PENDAHULUAN}

Indonesia merupakan negara kepulauan yang mempunyai potensi sumber daya ikan yang sangat melimpah. Hal ini menyebabkan sebagian besar dari penduduk Indonesia bermata pencaharian di bidang perikanan, baik di daratan maupun di lautan. Sehingga pemerintah memberikan perhatian yang besar dalam bidang perikanan laut ini karena menyadari besarnya kekayaan laut yang dimiliki oleh Indonesia dalam bidang ini yang juga berarti dapat menambah devisa negara selain itu, pemerintah juga membentuk suatu departemen yang mengurusi masalah masalah perikanan dan kelautan di Indonesia.

Di Aceh, kehadiran sub sektor perikanan diharapkan dapat memberikan sumbangan berharga bagi pembangunan NAD, terutama dalam mendukung pembangunan zona pertanian. Dalam hal ini pemerintah daerah NAD melalui Dinas Perikanan Kota Banda Aceh dan Balai Budidaya Air Payau telah berusaha melakukan upaya dalam meningkatkan produksi perikanan, terutama perikanan Air Payau yang berada di bawah Balai Budidaya Air Payau Ujung Batee.

Balai Budidaya Air Payau merupakan Unit Pelaksana Teknis (UPT) yang bernaung di bawah lingkungan Departemen Kelautan dan Perikanan. Unit ini terletak di Desa Durung
Ujung Batee Kecamatan Mesjid Raya Aceh Besar. Di tempat inilah beberapa jenis dari hewan air payau dibudidayakan, untuk melestarikan hewan air payau. Jenis - jenis hewan air payau yang dibudidayakan di BBAP ini adalah Ikan Kerapu Macan, Ikan Kerapu Kertang, Ikan Kerapu Bebek, Ikan Kerapu Lumpur, Ikan Bandeng, Udang Windu, Udang Putih, Udang Kelong

Ikan kerapu (Epinephelus) merupakan salah satu ikan laut komoditas ekspor bersama dengan beberapa jenis ikan lainnya. Ikan kerapu memiliki nilai ekonomis dan mengandung protein hewani yang sangat tinggi. Sehingga banyak masyarakat yang memasokkan ikan budidaya siap tebar ini karena banyaknya permintaan akan ikan kerapu. Namun sayangnya pemasokkan ikan budidaya siap tebar ini masih mengandalkan dari usaha penangkapan di alam. Dengan demikian dikhawatirkan akan menimbulkan pengeksplorasian penangkapan ikan di alam secara berlebihan Sehingga dapat mengganggu keseimbangan ekosistem. Salah satu strategi pelestarian dan pemanfaatan potensi sumber daya laut di Aceh adalah dengan dibuatnya pembenihan dan pembudidayaan ikan laut khususnya ikan kerapu, seperti halnya yang terdapat di BBAP Ujung Batee.

Guna memaksimalkan usaha ini, maka perlu didukung sumber daya manusia dengan 
menguasai tekhnologi. Selain itu juga dapat dianalisis dengan menggunakan analisis SWOT agar prospek pengembangan pembenihan ikan kerapu untuk kedepannya dapat berjalan dengan lebih baik. Selain itu juga perlu kiranya dilakukan suatu penelitian untuk melihat kelayakan dari usaha pembenihan ikan kerapu ini.

\section{Analisis Finansial \\ KAJIAN KEPUSTAKAAN}

Kinerja perusahaan tidak cukup hanya diukur berdasarkan laba akuntansi saja, karena laba akuntansi tidak mempunyai makna riil apabila apabila tidak didukung oleh kemampuan perusahaan dalam meningkatkan nilai tambah secara ekonomis (Supriyanto, $2015: 40$ ).

Menurut Kadariah (1978 : 39) ada lima kriteria investasi yang dapat digunakan untuk menentukan layak atau tidaknya perusahaan untuk dikembangkan, empat kriteria pertama yang umum dipakai dan dapat dipertanggungjawabkan untuk penggunaan tertentu sedangkan yang terakhir dapat kritikan dari segi teoritis, yaitu: Net Present Value (NPV), Net Benefit Cost Ratio (Net B/C), Internal Rate of Return (IRR), Break Event Point (BEP), Profitability Ratio (PR).

Berdasarkan kriteria - kriteria yang telah dikemukakan di atas, maka kriteria investasi dan analisis pendukung lainnya yang digunakan dalam penelitian ini adalah sebagai berikut:

\section{Net Present Value (NPV)}

Net Present Value sering diterjemahkan sebagai nilai bersih sekarang. Net Present Value adalah nilai sekarang (Present Value) dari selisih antara manfaat (Benefit) dengan biaya (Cost) pada Discount Rate tertentu (Choliq, 1993:34).

Jika Present Value manfaat lebih besar dari pada Present Value biaya, berarti usaha tersebut layak untuk diusahakan atau menguntungkan. Dengan kata lain NPV $>0$ berarti usaha tersebut menguntungkan. Sebaliknya jika NPV < 0 maka usaha tersebut tidak menguntungkan, Dengan rumus sebagai berikut :

$$
\mathrm{NPV}=\sum_{t=1}^{n} \frac{B_{t}-C_{t}}{(1+i)^{t}} \ldots . .(\text { Kadariyah, 1978:51) }
$$

$$
\begin{array}{ll}
\mathrm{B}_{\mathrm{t}} & =\text { Benefit pada tahun ke } \mathrm{t} \\
\mathrm{C}_{\mathrm{t}} & =\text { Cost pada tahun ke } \mathrm{t} \\
\mathrm{i} & =\text { Tingkat bunga yang berlaku } \\
\mathrm{n} & =\text { Umur ekonomis }
\end{array}
$$

\section{Net Benefit Cost Ratio (Net B/C)}

Net B/C adalah perbandingan antara jumlah Net Present Value Positif (NPV Positif) dengan Net Present Value Negatif (NPV Negatif). Net B/C ini menunjukkan gambaran berapa kali lipat benefit akan diperoleh dari cost yang dikeluarkan (Choliq, 1993:36). Jika Net $\mathrm{B} / \mathrm{C}>1$ maka usaha layak untuk diusahakan, jika Net $B / C=1$, proyek layak dilaksanakan yang artinya penerimaan yang diperoleh dari usaha tersebut sama dengan biaya yang dikeluarkan, Dengan formula sebagai berikut :

Net B/C $=\frac{\sum_{t=1}^{n} \frac{B_{t}-C_{t}}{(1+i)^{t}}}{\sum_{t=1}^{n} \frac{C_{t}-B_{t}}{(1+i)^{t}}}$ (Kadariyah, 1978:56)

Keterangan:

$$
\begin{array}{ll}
\mathrm{B}_{\mathrm{t}} & =\text { Benefit pada tahun ke } \mathrm{t} \\
\mathrm{C}_{\mathrm{t}} & =\text { Cost pada tahun ke } \mathrm{t} \\
\mathrm{i} & =\text { Tingkat bunga yang berlaku } \\
\mathrm{n} & =\text { Umur ekonomis }
\end{array}
$$

\section{Internal Rate of Return (IRR)}

IRR merupakan nilai untuk mengetahui persentase keuntungan dari suatu proyek tiap tiap tahun dan IRR juga merupakan alat ukur kemampuan proyek dalam mengembalikan bunga pinjaman (Choliq, 1993:40). Apabila IRR lebih besar dari bunga bank maka usaha layak untuk diusahakan. Rumus sbb :

$$
\mathrm{IRR}=i_{1}+\frac{N P V_{1}}{N P V_{1}-N P V_{2}}\left(i_{2}-i_{1}\right)
$$

(Ibrahim, 1998:147)

$$
\begin{array}{ll}
\text { NPV }_{1} & =\text { Nilai NPV pada tingkat bunga } i_{1} \\
N P V_{2} & =\text { Nilai NPV pada tingkat bunga } i_{2} \\
i_{1} & =\text { Tingkat bunga pertama (NPV positif) } \\
i_{2} & =\text { Tingkat bunga kedua (NPV negatif) } \\
n & =\text { Umur ekonomis }
\end{array}
$$

\section{Break Event Point (BEP)}

BEP adalah suatu saat dimana arus benefit secara komulatif mampu menutupi total cost (Syakhiruddin, 1981:67). Dengan kata lain BEP digunakan untuk melihat kapan suatu usaha itu mengembalikan modal.

Menurut Ibrahim (1998:155) BEP adalah titik pulang pokok dimana total revenue sama dengan total cost. Jika BEP lebih kecil dari umur ekonomis maka usaha layak diusahakan. Dengan formula sebagai berikut :

$\mathrm{BEP}=\mathrm{T}_{\mathrm{p}-1}+\frac{\sum_{i=1}^{n} T C_{i}-\sum_{i=1}^{n} B_{i c p-1}}{B_{p}}$.

(Ibrahim, 1998:156)

$\mathrm{T}_{\mathrm{p}-1} \quad=$ Tahun sebelum terdapat BEP 


$$
\begin{array}{ll}
\mathrm{TC}_{\mathrm{i}}=\begin{array}{l}
\text { Jumlah total cost yang telah di } \\
\text { discount }
\end{array} \\
\mathrm{B}_{\mathrm{icp}-1}=\begin{array}{l}
\text { Jumlah benefit yang telah di discount } \\
\text { sebelum BEP }
\end{array} \\
\begin{array}{cl}
\mathrm{B}_{\mathrm{p}} & =\text { Jumlah benefit pada BEP berada } \\
\mathrm{N} & =\text { Umur ekonomis }
\end{array}
\end{array}
$$

\section{Return of Investment (Rol)}

Menurut Su'ud (2005:31) Rol adalah suatu metode untuk mengukur kemampuan suatu perusahaan secara keseluruhan dalam menghasilkan keuntungan dalam jumlah keseluruhan aktiva yang tersedia pada perusahaan. Semakin tinggi rasio yang diperoleh memberikan gambaran semakin baik kondisi perusahaan sehingga makin layak untuk diusahakan, dengan rumus sebagai berikut:

$$
\mathrm{Rol}=\frac{\text { Keuntungan }(\text { Rp / ekor })}{\operatorname{Modal}(\mathrm{Rp})} \times 100 \%
$$

(Cahyono, 2003:121)

\section{Analisis Pendukung Lainnya Pay Back Periods (PBP)}

Menurut Ibrahim (1998:154) Payback Period adalah jangka waktu tertentu yang menunjukkan terjadinya arus penerimaan (cash in flows) secara komulatif sama dengan jumlah investasi dalam bentuk present value. Jika PBP lebih kecil dai umur ekonomis maka usaha layak diusahakan.

$\mathrm{PBP}=\mathrm{T}_{\mathrm{p}-1}+\frac{\sum_{i=1}^{n} I_{i}-\sum_{i=1}^{n} B_{i c p-1}}{B_{p}}$

(Ibrahim, 1998:154)

$$
\begin{aligned}
& \mathrm{T}_{\mathrm{p}-1}=\text { Tahun sebelum terdapat PBP } \\
& \mathrm{I}_{\mathrm{p}} \quad=\text { Jumlah investasi yang telah di } \\
& \text { discount } \\
& \mathrm{B}_{\text {icp-1 }}=\text { Jumlah benefit yang telah di discount } \\
& \text { sebelum PBP } \\
& \mathrm{B}_{\mathrm{p}} \quad=\text { Jumlah benefit pada PBP } \\
& \mathrm{n}=\text { Umur ekonomis }
\end{aligned}
$$

\section{Analisis Sensitivitas}

Menurut Kadariyah (1978: 98) dalam melaksanakan suatu proyek juga perlu suatu analisis sensitivitas (analisis kepekaan), yaitu suatu analisis yang dilakukan untuk melihat apa yang akan terjadi dengan hasil analisis proyek jika ada kesalahan atau perubahan dalam dasar-dasar perhitungan biaya dan manfaat. Hal ini dilakukan mengingat biaya-biaya yang digunakan dalam suatu proyek sering berfluktuasi di waktu yang akan datang.

Dalam menggunakan Analisis Sensitivitas digunakan beberapa asumsi yaitu sebagai berikut:

Kemungkinan I : Biaya Operasional naik $10 \%$, manfaat tetap
Kemungkinan II : Biaya Operasional tetap, manfaat turun $10 \%$.

SWOT

Analisis SWOT yang digunakan dalam penelitian ini terdiri dua faktor lingkungan yaitu faktor lingkungan internal dan eksternal. Faktor - faktor tersebut terdiri dari :

Faktor Lingkungan Internal yaitu :

1. Kekuatan (Strenght) yaitu segala aspek yang mempengaruhi kegiatan pemasaran perusahaan di dalam menguasai pasar.

2. Kelemahan (Weakness) yaitu Segala aspek yang mempengaruhi kegiatan pasar perusahaan di dalam menguasai pasar

Faktor Lingkungan Eksternal yaitu meliputi :

3. Peluang (Oppotunity) yaitu Kesempatan yang umumnya dipengaruhi oleh aspek - aspek di luar kegiatan pemasaran perusahaan dalam meraih target pasar.

4. Ancaman (Threat) yaitu Tantangan yang umumnya dipengaruhi oleh aspek - aspek di luar kegiatan pemasaran perusahaan dalam meraih target pasar.

Tahapan kegiatan yang harus dilakukan sebelum membuat matrik SWOT adalah sebagai berikut :

Menentukan faktor - faktor strategis internal dan eksternal.

Merumuskan alternatif strategi dengan membuat Matrik Internal - Eksternal dan Matrik SWOT

\section{METODE PENELITIAN \\ Lokasi dan Objek Penelitian}

Penelitian ini dilakukan di Balai Budidaya Air Payau Ujung Batee Desa Neuhen Kecamatan Mesjid Raya Kabupaten Aceh Besar. Objek penelitian ini adalah Balai Budidaya Air Payau Ujung Batee, sedangkan ruang lingkup dari penelitian ini hanya terbatas pada analisis SWOT dan analisis finansial pada pembenihan ikan kerapu pada Balai Budidaya Air Payau Ujung Batee.

Metode yang digunakan dalam penelitian ini adalah metode studi kasus, karena metode ini mengungkapkan suatu kebenaran yang menitik beratkan hanya pada satu objek penelitian yaitu pembenihan ikan kerapu pada BBAP Ujung Batee Kecamatan Mesjid Raya Kabupaten Aceh Besar.

\section{Batasan Variabel}

Variabel yang digunakan dalam penelitian ini adalah sebagai berikut :

Biaya Produksi yaitu seluruh biaya yang dikeluarkan oleh BBAP Ujung Batee dalam melaksanakan usaha pembenihan ikan kerapu. Biaya ini terdiri dari biaya investasi dan biaya operasional (Rp/tahun).

Biaya Investasi yaitu semua biaya yang dikeluarkan selama periode tertentu sebelum usaha tersebut mendapatkan manfaat (Rp). 
Biaya Operasional adalah biaya - biaya yang dikeluarkan selama proses produksi atau ketika usaha tersebut telah mendapatkan hasil (Rp/tahun).

Produksi merupakan jumlah hasil produksi dalam bentuk fisik dari proses hasil produksi (ekor/tahun).

Nilai Produksi adalah penerimaan kotor yang diperoleh dari perkalian hasil produksi yang dihasilkan dengan harga yang berlaku saat penelitian (Rp/tahun).

Harga merupakan besarnya harga jual hasil panen benih ikan yang berlaku pada saat penelitian (Rp/ekor).

Keuntungan adalah hasil pengurangan dari penerimaan dan biaya total atau juga dapat disebut dengan penerimaan bersih (Rp/tahun).

Tenaga Kerja adalah setiap tenaga manusia yang ikut melaksanakan seluruh kegiatan usaha pembenihan ikan kerapu (Rp/tahun.)

Umur Ekonomis adalah lamanya waktu yang dibutuhkan suatu proyek ketika masih produktif, dalam hal ini pembenihan ikan kerapu, dimana umur ekonomisnya 10 tahun.

SWOT merupakan identifikasi dari berbagai faktor secara sistematis untuk merumuskan strategi perusahaan.

\section{HASIL PENELITIAN DAN PEMBAHASAN Analisis Finansial}

Analisis finansial adalah analisis terhadap arus pengeluaran dan penerimaan dari suatu kegiatan. Analisis finansial sering juga disebut analisis perhitungan laba rugi suatu perusahaan, dalam hal ini kegiatan usaha tani.

Dalam usaha ini digunakan beberapa analisis yaitu : Net Present Value (NPV), Net Benefit Cost Ratio (B/C Ratio), Internal Rate of Return (IRR), Break Event Point (BEP), Payback Periods (PBP), Return of Investment (Rol) dan Analisis Sensitivitas :
a. NPV
:Rp. 811.133.457,--
b. Net B/C
: 2,07
c. IRR
d. BEP
e. PBP
: 43,16\%.
: Tahun ke 3 bulan ke 6 , hari ke 10.
f. Rol
: Bulan ke 7, hari ke 24.
g. Analisis Sensitivitas

- Biaya operasional naik $10 \%$, manfaat tetap : NPV (Rp.604.453.855), Net B/C $(1,73)$, IRR $(35,40 \%)$, BEP(Tahun ke 4 bulan ke 9 hari ke 25), PBP(Tahun ke 1 bulan ke 7 hari ke 24), Rol (30,50\%)

- Manfaat turun $10 \%$, biaya operasional tetap : NPV (Rp.433.907.509), Net B/C $(1,53), \operatorname{IRR}(30,47 \%)$, BEP (Tahun ke 5 bulan ke 4 hari ke 27), PBP (Tahun ke 2 Analisis SWOT

Hasil dari analisis SWOT didapat strategi Internal diperoleh skor pembobotan sebanyak 2,84 dan tabel faktor strategi eksternal sebanyak 2,80. Jika dimasukkan ke dalam Matrik Internal - Eksternal (Lampiran 16) maka strategi yang tepat untuk usaha ini berada pada sel ke $\mathrm{V}$ yaitu sel pertumbuhan / stabilitas ( strategi konsentrasi melalui integrasi horizontal ).

Adapun tujuannya relatif lebih defensif atau bertahan yaitu untuk menghindari kehilangan penjualan dan kehilangan profit. Strategi yang dapat dilakukan untuk mengatasinya yaitu dengan memperluas pasar, fasilitas produksi dan teknologi melalui pengembangan internal maupun eksternal dengan cara akuisisi.

\section{KESIMPULAN}

Usaha pembenihan ikan kerapu di BBAP Ujung Batee ini layak diusahakan bila ditinjau dari segi biaya dan manfaat, hal ini disebabkan usaha ini memenuhi syarat - syarat dari beberapa kriteria investasi yang merupakan tolak ukur layak atau tidaknya usaha pembenihan ini untuk dijalankan.

Berdasarkan data - data yang diperoleh selama penelitian, terdapat beberapa strategi yang tepat dari analisis SWOT yang dapat digunakan untuk pengembangan BBAP Ujung Batee ke depannya. Strategi yang dapat diterapkan yaitu konsolidasi, tujuannya relatif lebih defensif, yaitu menghindari kehilangan penjualan dan kehilangan profit. Perusahaan yang berada di sel ini dapat memperluas pasar, fasilitas produksi dan teknologi melalui pengembangan internal maupun eksternal.

\section{DAFTAR PUSTAKA}

Aprilawati. 2006. Makalah Teknik Pemeliharaan Calon Induk Ikan Kerapu Kertang di Loka Bodidaya Air Payau Ujung Batee (Tidak dipublukasikan). IImu Kelautan FMIPA. Unsyiah. Banda Aceh.

Cahyono, Ir. Bambang. 2003. Timun. Aneka IImu. Semarang.

Choliq, Abdul. 1993. Evaluasi Proyek, Suatu Pengantar. Pionir Jaya. Bandung.

Fitriadi, Suirfan. 2007. Makalah Teknik Pematangan Gonad Induk Kerapu Macan dengan Menggunakan Vitamin MIX di BBAP Ujung Batee (Tidak dipublikasikan). IImu Kelautan FMIPA. Unsyiah. Banda Aceh.

Ibrahim, Yacob. 1998. Studi Kelayakan Bisnis. Rineka Cipta, Jakarta.

Idris, I. (2014). Cost Benefit Analysis untuk kelayakan investasi Sistem Informasi Terintegrasi pada Perguruan Tinggi 
Swasta (studi kasus Politeknik LP3I Medan). In PROSIDING Seminar Nasional Inovasi dan Teknologi Informasi (pp. 206209).

Kadariyah, dkk. 1978. Pengantar Evaluasi Proyek. Fakultas Ekonomi Universitas Indonesia, Jakarta.

M. Ghufran. H dan K Kordi. 2001. Usaha Pembesaran Ikan Kerapu di Tambak. Kanisius Yogyakarta.

Marsambuan A.P dan Utojo. 2001. Identifikasi Spesies Ikan Kerapu Hasil Tangkapan yang di Daratkan di Perairan Laut sekitar Sulawesi Selatan. Teknologi Budidaya Laut dan Pengembangan Sea Farming di Indonesia. DKP kerjasama JICA

Murtidjo,Bambang Agus. 2002. Budidaya Kerapu dalam Tambak. Kanisius. Yogyakarta.

Mustahal, Dr. Sunyoto, Pramu, Drs. 2004. Pembenihan Ikan Laut Ekonomis (Kerapu, Kakap, Beronang). Penebar Swadaya. Jakarta.

Rangkuti, Freddy. 1997. Analisis SWOT Teknik Membedah Kasus Bisnis. Gramedia Putra Utama. Jakarta.

Ranita, S. V., \& Hanum, Z. (2018). REVENUE COST DAN ANALISIS SWOT DALAM PENGEMBANGAN USAHA. Jurnal Bis-A: Jurnal Bisnis Administrasi, 5(2), 14-19.

Soekartawi, 1986. IImu Usahatani dan Penelitian untuk Pengembangan Petani Kecil. UI, Jakarta.

Suci, DA Sanjaya, I Idris, RA Sari, Supriyanto, MM Ritonga. (2018). SWOT Analysis as Strategy to Improve Competitiveness of Durian Pancake Medium Enterprises. Journal Online Jaringan COT POLIPD 12 (2), 9-20.

Sukirno, S. 2003. Pengantar Teori Mikroekonomi. Raja Grafindo. Jakarta.

Supriyanto, S. (2018). Pengaruh Kinerja Keuangan Terhadap Pendapatan Saham Perbankan Di Bursa Efek Indonesia. Jurnal Bis-A: Jurnal Bisnis Administrasi, 2(1), 39-53.

Syakhiruddin. 1981. Analisis Perencanaan Proyek. Fakultas Ekonomi Universitas Syiah Kuala. Banda Aceh. 